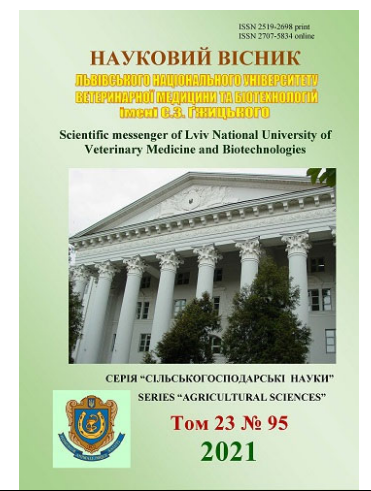

Науковий вісник Дьвівського національного університету ветеринарної медицини та біотехнологій імені С.3. Гжицького. Серія: Сільськогосподарські науки

\author{
Scientific Messenger of Lviv National University \\ of Veterinary Medicine and Biotechnologies. \\ Series: Agricultural sciences
}

doi: 10.32718/nvlvet-a9511

https://nvlvet.com.ua/index.php/agriculture

UDC 636:636.5:612.014.44

\title{
Influence of light wavelength on viability and reproductive function of hens
}

\author{
Yu. V. Osadcha ${ }^{1}$, G. I. Sakhatsky² \\ ${ }^{1}$ National University of Life and Environmental Sciences of Ukraine, Kyiv, Ukraine \\ ${ }^{2}$ Priazov State Technical University, Mariupol, Ukraine
}

\section{Article info}

Received 14.05.2021

Received in revised form 17.06.2021

Accepted 18.06.2021

National University of Life and Environmental Sciences of Ukraine, Heroyiv Oborony Str., 15, Kyiv, 03041, Ukraine. Tel.: +38-067-753-27-27

E-mail: seledat@ukr.net

Priazov State Technical University, University Str., 7, Mariupol, 87555, Ukraine.

Tel: $+38-067-776-43-10$

E-mail: sakhatsky13@ukr.net
Osadcha, Yu. V., \& Sakhatsky, G. I. (2021). Influence of light wavelength on viability and reproductive function of hens. Scientific Messenger of Lviv National University of Veterinary Medicine and Biotechnologies. Series: Agricultural sciences, 23(95), 76-81. doi: 10.32718/nvlveta9511

The article presents the results of influence of monochrome light with different light wavelengths on the hens' viability and productivity. For this purpose, in the conditions of a modern complex for production of food eggs in a poultry house with an area of $2915 \mathrm{~m}^{2}, 4$ groups of hens of the industrial herd "Hy-Line W36 " were formed, each of which was kept in a separate poultry house similar in area and cage equipment. Each poultry house was equipped with "Big Dutchman" cage batteries, consisting of 1176 cages with an area of $40544 \mathrm{~cm}^{2}$. The differences between the poultry houses applied only to LED lamps. Hens of the $1^{\text {st }}$ group were kept using LED lamps with a peak light wavelength of $458 \mathrm{~nm}$ (blue color of the spectrum), the $2^{\text {nd }}$ group $-603 \mathrm{~nm}$ (yellow color of the spectrum), the $3^{\text {rd }}$ group $-632 \mathrm{~nm}$ (orange color of the spectrum) and 4 groups - $653 \mathrm{~nm}$ (red color of the spectrum). Every day, for 34 weeks of the productive period (up to 52 weeks of age), the number of eggs laid by the laying hens of each group was determined. The number of hatched hens (due to death and culling) was also counted daily and the number of livestock was determined. Once a week, the weight of eggs and live weight of laying hens were measured from certain labeled cages. It was found that the reduction of the wavelength of light during the keeping of hens in the cages of multitiered batteries affects their viability and reproductive function. The decrease in the peak wavelength from 653 to $632 \mathrm{~nm}$, which was manifested by a change in the color of light from red to orange, was accompanied by a decrease in the preservation by $0.3 \%$, body weight - by $0.8 \%$, egg laying on the initial laying by $3.1 \%$, egg-laying per average laying hen - by $2.8 \%$ and feed costs - by $0.2 \%$. The decrease in the peak wavelength to $603 \mathrm{~nm}$, that is the change in the color of light from red and orange to yellow, was accompanied by a decrease in the preservation by $6.4-6.7 \%$, body weight - by 0.5-1.3\%, egg production by initial laying hen - by 7.1-10.0\%, laying hens on the average laying hen - by $0.4-3.2 \%$ and feed costs - by 2.0 $2.1 \%$. The decrease in the peak wavelength to $458 \mathrm{~nm}$, that is the change in light color from red, orange and yellow to blue, was accompanied by a decrease in the preservation by 3.2-9.9\%, body weight - by $5.2-$ $6.5 \%$, laying hens per initial laying hen - by 6.4-15.8\%, laying hens per middle laying hen - by $2.9-6.0 \%$ and feed costs - by $1.0-3.1 \%$.

Key words: laying hens, egg-laying, preservation, live weight, light wavelength, light color.

\section{Вплив довжини світлової хвилі на життєздатність та репродуктивну функцію курей}

\author{
Ю. В. Осадча ${ }^{1}$, Г. І. Сахацький
}

${ }^{1}$ Національний університет біоресурсів і природокористування Украӥни, м. Київ, Украӥна

${ }^{2}$ Приазовський державний технічний університет, м. Маріуполь, Украйна

Досліджено вплив монохромного світла з різною довжиною світлової хвилі на життєздатність та репродуктивну функиію курей. Для изього в умовах сучасного комплексу з виробництва харчових яєць у пташнику площею 2915 м² сформували 4 групи яєчних курей промислового стада "Ну-Liпе W-36", кожну з яких утримували у окремому пташнику-аналогу за площею та клітковим устаткуванням. Кожен пташник був обладнаний клітковими батареями “Вig Dиtсhтап”, щзо складалися з 1176 кліток площею

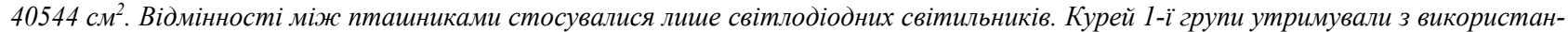
Scientific Messenger LNUVMB. Series: Agricultural sciences, 2021, vol. 23, no 95 
ням світлодіодних світильників із піковою довжиною світлової хвилі 458 нм (блакитний колір спектру), 2-ї групи - 603 нм (жовтий колір спектру), 3-ї групи - 632 нм (помаранчевий колір спектру) та 4-ї групи - 653 нм (червоний колір спектру). Щодня, упродовж 34 тижнів продуктивного періоду (до 52-тижневого віку), визначали кількість яєць, знесених несучками кожної групи. Здійснювали також щуодня облік кількості курей, щуо вибули (через падіж і вибракування) та визначали збереженість поголів'я. Раз на тиждень вимірювали масу яєць та живу масу несучок з певних маркованих кліток. Виявлено, шуо зменшення довжини хвилі світла під час утримання курей в клітках багатоярусних батарей чинить вплив на їхню життєздатність та репродуктивну функцію. Зменшення пікової довжини хвилі від 653 до 632 нм, яке проявлялося зміною кольору світла з червоного до помаранчевого, супроводжувалось подальшим зниженням збереженості поголів'я на 0,3%, маси тіла - на 0,8\%, несучості на початкову несучку - на 3,1\%, несучості на середню несучку - на 2,8\% та витрат корму - на 0,2\%. Зменшення пікової довжини хвилі до 603 нм, тобто зміна кольору світла з червоного та помаранчевого на жовте, супроводжувалось зниженням збереженості поголів'я на 6,4-6, 7 \%, маси тіла - на 0,5-1,3\%, несучості на початкову несучку - на 7,1-10,0\%, несучості на середню несучку - на 0,4-3,2 \% та витрат корму - на 2,0-2,1\%. Зменшення ж пікової довжини хвилі до 458 нм, тобто зміна кольору світла з червоного, помаранчевого та жовтого на блакитне, супроводжувалось наростаючим зниженням збереженості поголів'я на 3,2-9,9\%, маси тіла - на 5,2-6,5 \%, несучості на початкову несучку - на 6,4-15,8\%, несучості на середню несучку - на 2,9-6,0\% та витрат корму - на 1,0-3,1\%.

Ключові слова: кури-несучки, несучість, збереженість, жива маса, довжина світлової хвилі, колір світла.

\section{Вступ}

Штучне світло як фактор навколишнього середовища, має вирішальне значення для вивільнення гормонів, які відіграють ключову роль у життєдіяльності, рості, імунітеті та розмноженні птиці (Patel et al., 2016). Для курей-несучок світло відіграє важливу роль у розвитку та функціонуванні репродуктивної системи, істотно впливаючи на вік знесення першого яйця, несучість та продуктивність загалом (Min et al., 2012; Huber-Eicher et al., 2013; Li et al., 2020).

Джерелом штучного світла останнього покоління у птахівництві є світлодіодні світильники (LED). Порівняно із лампами розжарювання та люмінесцентними лампами, світлодіодні мають більший термін служби, специфічний спектр, меншу теплову потужність, вищу енергоефективність та надійність, а також менші витрати на обслуговування (Prayitno et al., 1997; Sultana et al., 2013; Yang et al., 2016), тому все частіше використовуються виробничниками (Shi et al., 2019).

Світлодіоди (LED) - це особливий вид напівпровідникових діодів, які можуть давати монохромне світло. Колір світла визначається довжиною хвилі видимого спектру, а монохромне світло має одну пікову довжину світлової хвилі (Yenilmez et al., 2021). На відміну від багатьох видів тварин, кури мають здатність бачити довжину світлової хвилі у вузькому діапазоні - від 380 до 760 нм, а також можуть розрізняти колір світла (Prescott \& Wathes, 1999). У них, крім очей, у трансдукції фотостимуляції беруть участь позасітківкові фоторецептори, розташовані в гіпоталамусі та в інших ділянках мозку (Rozenboim et al., 1999). Тому світло $є$ ефективним чинником контролю фізіологічних та поведінкових процесів, які впливають на несучість курей та якість їхніх яєць (Yenilmez et al., 2021).

Доведено, що довжина хвилі світла впливає на поведінку, добробут та продуктивність птиці (Manser, 1996; Rozenboim et al., 1999; Svobodova et al., 2015). Однак аналіз попередніх досліджень показує, що дані про вплив монохромного світла на несучість курей та якість їхніх яєць досить суперечливі. Так, за даними одних дослідників (Li et al., 2019), використання блакитного світла, порівняно з білим, зеленим та червоним, сприяє підвищенню несучості курей. Блакитний спектр світла також стимулює підвищення концент- рації фолікулостимулюючого гормону у крові курей, однак за використання червоного світла підвищується концентрація лютеїнізуючого гормону (Mudhar \& Tabeekh, 2016). На думку ж інших вчених, використання саме червоного спектру світла сприяє підвищенню несучості курей (Hassan et al., 2013; Zhang et al., 2017) та товщини яєчної шкаралупи (Kim et al., 2010), а блакитного та зеленого - підвищенню маси яєць (Hassan et al., 2013). Є також повідомлення про те, що використання червоного світла спричиняє значне зменшення маси яєць, а якість яєць поліпшується за використання зеленого світла (Er et al., 2007). Водночас рядом дослідників показано, що монохромне світло не впливає на несучість курей та якість їхніх яєць (Rozenboim et al., 1999; Lewis et al., 2007; Borille et al., 2013; Borille et al., 2015), а також не позначається на концентрації гормонів у крові (Li et al., 2015).

Тому метою роботи було вивчення впливу монохромного світла з різною довжиною світлової хвилі на життєздатність курей та їхню репродуктивну функцію.

\section{Матеріал і методи досліджень}

Як об'єкт досліджень використовували яєчних курей промислового стада "Hy-Line W-36". Досліди 3 експериментальними тваринами проводили відповідно до правил Європейської конвенції про захист хребетних тварин (Офіційний вісник Європейського Союзу L276/33, 2010).

В умовах сучасного комплексу з виробництва харчових яєць у пташнику площею 2915 м² сформували 4 групи яєчних курей промислового стада "Hy-Line W36", кожну з яких утримували в окремому пташникуаналогу за площею та клітковим устаткуванням. Кожен пташник був обладнаний клітковими батареями "Big Dutchman" (Німеччина), що складалися з 1176 кліток площею $40544 \mathrm{~cm}^{2}(362 \times 112 \mathrm{~cm})$. Відмінності між пташниками стосувалися лише світодіодних світильників (табл. 1). Так, курей 1-ї групи утримували 3 використанням світлодіодних світильників із піковою довжиною світлової хвилі 458 нм (блакитний колір спектра), 2-ї групи - 603 нм (жовтий колір спектра), 3ї групи - 632 нм (помаранчевий колір спектру) та 4-ї групи - 653 нм (червоний колір спектра). 
Таблиця 1

Схема досліду

\begin{tabular}{|c|c|c|c|c|}
\hline \multirow{2}{*}{ Характеристика } & \multicolumn{4}{|c|}{ Група курей } \\
\hline & 1 & 2 & 3 & 4 \\
\hline Пікова довжина хвилі, нм & 458 & 603 & 632 & 653 \\
\hline Колір спектру & блакитний & жовтий & помаранчевий & червоний \\
\hline Кількість голів у клітці & & 10 & & \\
\hline Кількість голів у групі & & 1187 & & \\
\hline Щільність посадки, гол./м² & & 401 & & \\
\hline Забезпеченість площею, см²/гол. & & 24 & & \\
\hline Площа клітки, см² & & 405 & & \\
\hline Кількість ніпелів у клітці, шт. & & 12 & & \\
\hline Фронт годівлі, см & & 7,8 & & \\
\hline Площа пташника, м² & & 291 & & \\
\hline
\end{tabular}

Упродовж досліду курей забезпечували питною водою, повнораціонними комбікормами однакового складу та утримували згідно з вимогами (ВНТП-АПК04.05). Щодня, упродовж 34 тижнів продуктивного періоду, визначали кількість яєць, знесених несучками кожної групи та інтенсивність їхньої несучості. Здійснювали також щодня облік кількості курей, що вибули (через падіж і вибракування) та визначали збереженість поголів'я. Раз на тиждень вимірювали масу яєць та живу масу несучок 3 певних маркованих кліток за вибіркою, яка становила не менше ніж 100 $(\mathrm{n} \geq 100)$.

Отримані цифрові результати опрацьовували методами варіаційної статистики. Достовірність відмінностей між середніми величинами визначали за tкритерієм Стьюдента, різниці вважали достовірними за $\mathrm{P}<0,05$.

\section{Результати та їх обговорення}

Для вивчення впливу кольору світла на вираження основних господарсько корисних ознак курей була проведена оцінка їх збереженості, маси тіла та продуктивності у віці 52 тижні (табл. 2). Виявлено, що збереженість поголів'я у всіх групах була нижчою за рівень $(97,4$ \%), рекомендований фірмою розробником кросу "Hy-Line W-36" (Hy-Line W-36 Final Hybrid
Content Guide, 2019), що може бути пов'язано з особливостями утримання великих масивів птиці (337-361 тис. гол.) в багатоярусних кліткових батареях нових конструкцій. Водночас простежувалось зниження збереженості поголів'я зі зменшенням довжини хвилі світла. Найбільша різниця - 12,2 \% 3 рекомендованим рівнем збереженості виявлена у курей 1-ї групи, яких утримували за блакитного світла, несучки 2-ї групи, яких утримували за жовтого світла, не досягали нормативу на 9,0 \%, тимчасом як у несучок 3-ї та 4-ї груп, яких утримували за помаранчевого та червоного світла, збереженість була майже на одному рівні і на 2,62,3 \% не досягала нормативу (рис. 1). Водночас збереженість поголів'я у курей 1-ї групи, яких утримували за блакитного світла, була нижчою на 3,2 \% (P < 0,001) порівняно з 2-ю групою та на 9,6 \% $(\mathrm{P}<0,001)$ i 9,9 \% (Р < 0,001) порівняно з 3-ю та 4-ю групами відповідно. У курей 2-ї групи, яких утримували за жовтого світла, збереженість була нижчою на 6,4 \% (P < $0,001)$ та $6,7 \%(\mathrm{P}<0,001)$ порівняно 3 3-ю та 4-ю групами відповідно, а у курей 3-ї групи, яких утримували за помаранчевого світла, збереженість була нижчою на 0,3 \% (P < 0,001) порівняно 3 курми 4-ї групи, яких утримували за червоного світла. Вищу збереженість поголів'я курей за використання червоного світла описують і інші дослідники (Svobodova et al., 2015).

\section{Таблиця 2}

Збереженість, маса тіла та продуктивність курей за різної довжини світлової хвилі (x \pm SE, n = 475104)

\begin{tabular}{|c|c|c|c|c|}
\hline \multirow{2}{*}{ Показники } & \multicolumn{4}{|c|}{ Група несучок } \\
\hline & 1 & 2 & 3 & 4 \\
\hline Несучок в групі, гол. & 475104 & 475104 & 475104 & 475104 \\
\hline Пікова довжина хвилі, нм & 458 & 603 & 632 & 653 \\
\hline Колір спектру & блакитний & жовтий & помаранчевий & червоний \\
\hline Збереженість поголів’я, \% & $85,2 \pm 0,10$ & $88,4 \pm 0,09^{* *}$ & $94,8 \pm 0,06^{* * \circ}$ & $95,1 \pm 0,06^{* * \circ 1}$ \\
\hline Маса тіла несучок, г & $1462 \pm 0,28$ & $1543 \pm 0,12^{* *}$ & $1551 \pm 0,26^{* * \circ}$ & $1563 \pm 0,11^{* * \circ 1}$ \\
\hline Несучість на початкову несучку, шт. & $169,9 \pm 0,14$ & $181,6 \pm 0,17^{* *}$ & $195,5 \pm 0,11^{* * \circ}$ & $201,7 \pm 0,19^{* * \circ \mathrm{\prime}}$ \\
\hline Несучість на середню несучку, шт. & $199,4 \pm 0,16$ & $205,4 \pm 0,10^{* *}$ & $206,2 \pm 0,07^{* * o}$ & $212,1 \pm 0,11^{* * 0 "}$ \\
\hline Маса яєць, г & $63,2 \pm 0,05$ & $63,0 \pm 0,06^{*}$ & $63,1 \pm 0,07$ & $63,3 \pm 0,04^{\circ}$ \\
\hline Витрати корму, г/гол./добу & $113,8 \pm 0,09$ & $114,9 \pm 0,11^{* *}$ & $117,2 \pm 0,06^{* * \circ}$ & $117,4 \pm 0,02^{* * * 1}$ \\
\hline
\end{tabular}

Спостерігалось також зниження маси тіла курей зі зменшенням довжини хвилі світла. Зокрема, маса тіла несучок 2-4-ї груп відповідала нормативній (Hy-Line W-36 Final Hybrid Content Guide, 2019) та знижува- лась в ії межах (1,54-1,58 кг), а 1-ї групи - не досягала нормативу на 5,1%. Так, кури 1-ї групи, яких утримували за блакитного світла, характеризувались нижчою масою тіла на 5,2% (P < 0,001) порівняно з 2-ю гру- 
пою та на 5,7 \% $(\mathrm{P}<0,001)$ та 6,5 \% $(\mathrm{P}<0,001)$ порівняно 3 3-ю і 4-ю групами відповідно. Своєю чергою кури 2-ї групи, яких утримували за жовтого світла, мали меншу масу тіла на $0,5 \%$ та $1,3 \%$ (P < 0,001) порівняно з 3-ю і 4-ю групами відповідно, а кури 3-ї групи, яких утримували за помаранчевого світла, - на 0,8 \% $(\mathrm{P}<0,001)$ порівняно з 4-ю групою, в якій курей утримували за червоного світла.

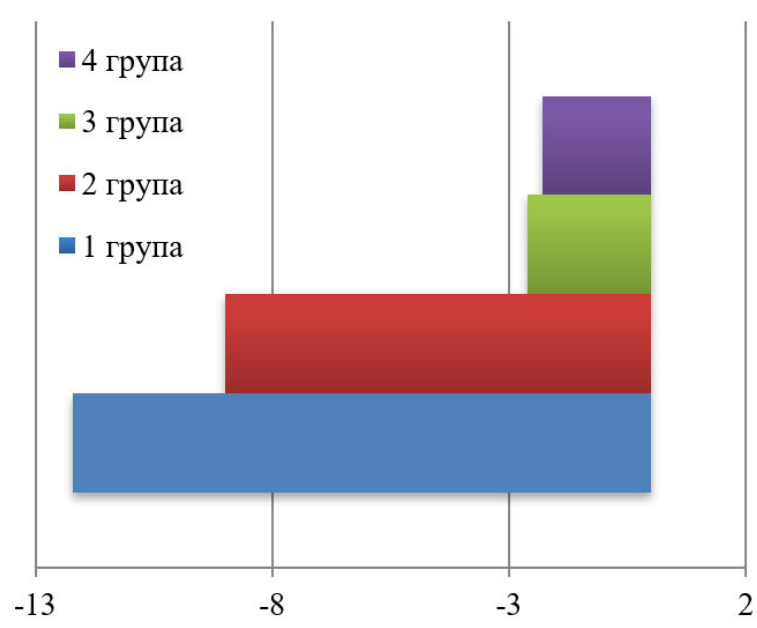

Збереженість поголів'я, \%

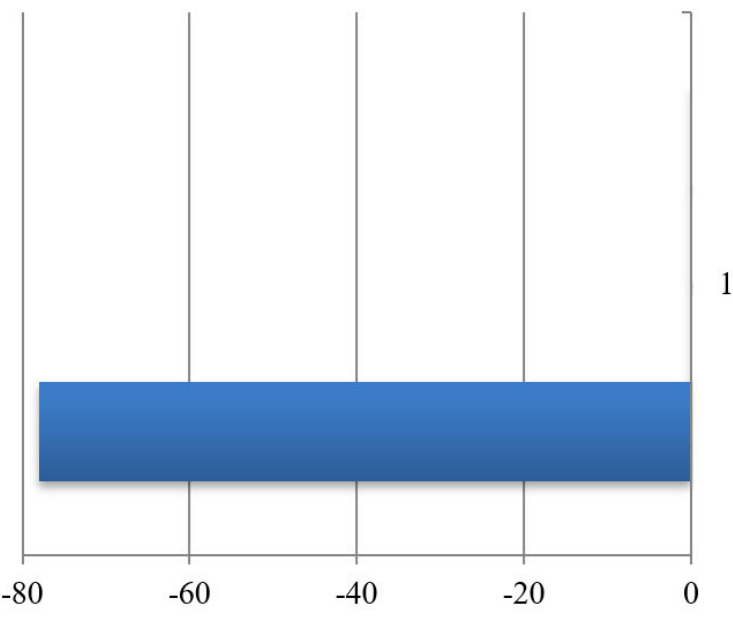

Жива маса, г

Рис. 1. Відхилення збереженості та живої маси несучок від нормативного рівня

Несучість на початкову несучку також знижувалася зі зменшенням довжини хвилі світла. Так, несучість на початкову несучку, згідно нормативних вимог, у віці 52 тижні повинна варіювати в межах 204,1-209,6 шт., а на середню - 206,9-212,5 шт. (Hy-Line W-36 Final Hybrid Content Guide, 2019). Фактично ж на початкову несучку - несучість жодної 3 груп не досягла нормативного рівня (рис. 2). Найнижча несучість та відповідно найбільше відхилення від нормативу - 16,8 \%, спостерігалась у курей 1-ї групи, яких утримували за блакитного світла. Водночас несучість на початкову несучку у них була нижчою на
$6,4 \%$ (P $<0,001)$ порівняно з 2-ю групою та на $13,1 \%$ $(\mathrm{P}<0,001)$ і 15,8 \% $(\mathrm{P}<0,001)$ порівняно 3 3-ю та 4-ю групами відповідно. У курей 2-ї групи, яких утримували за жовтого світла, несучість на початкову несучку була нижчою за нормативну на $11,0 \%$, а також на $7,1 \%(\mathrm{P}<0,001)$ і 10,0 \% (P < 0,001) порівняно 3 3-ю та 4-ю групами відповідно. Кури 3-ї групи, яких утримували за помаранчевого світла, не досягали нормативу на 4,2 \% та поступалися на 3,1 \% (P < 0,001) курям 4-ї групи. Своєю чергою кури 4-ї групи, яких утримували за червоного світла, не досягали нормативу лише на $1,2 \%$.

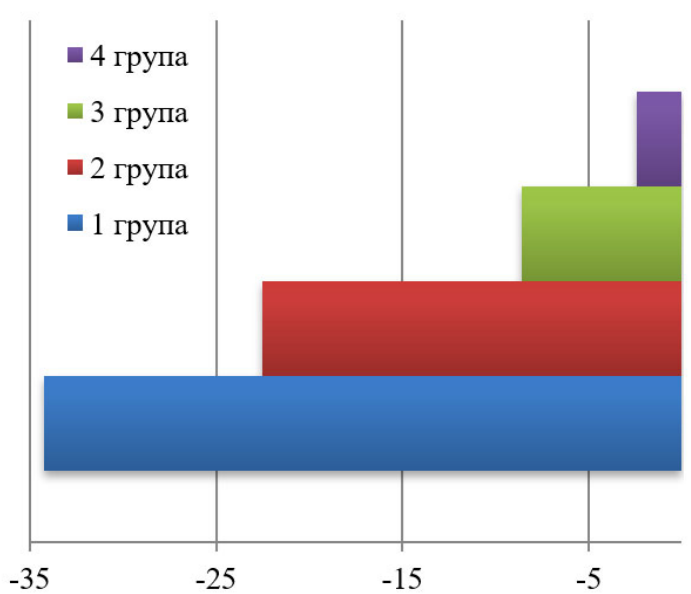

Несучість на початкову несучку, шт.

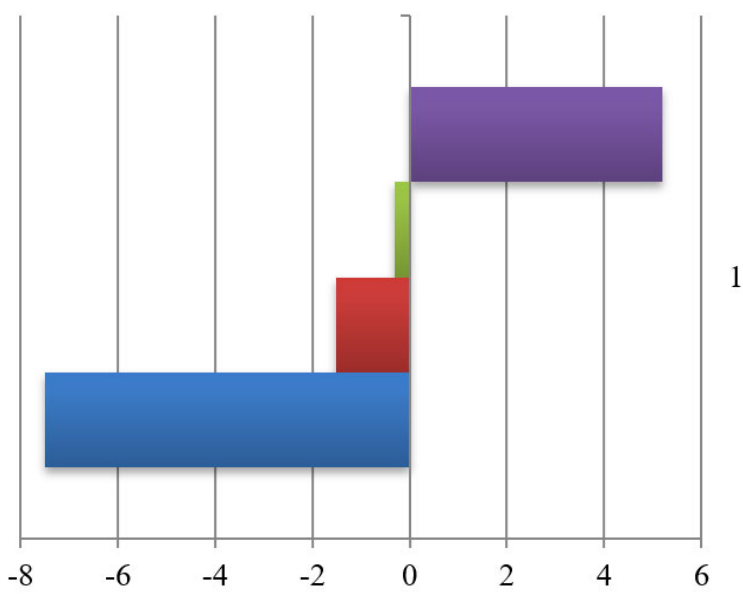

Несучість на середню несучку, шт.

Рис. 2. Відхилення несучості курей дослідних груп від нормативного рівня

За несучістю на середню несучку нормативного рівня було досягнуто лише курми 4-ї групи. Найнижча несучість на середню несучку та відповідно найбільше відхилення від нормативу - 3,6 \% спостерігалась у курей 1-ї групи, яких утримували за блакитного світла. Водночас несучість на середню несучку у них була нижчою на 2,9 \% (P < 0,001) порівняно 3 2-ю групою та на $3,3 \%(\mathrm{P}<0,001)$ і $6,0 \%(\mathrm{P}<0,001)$ порівняно 3 3-ю та 4-ю групами відповідно. Несучість на середню несучку у курей 2-ї групи, яких утримували за жовтого світла, була нижчою за норматив на $0,7 \%$ та на $0,4 \%(\mathrm{P}<0,001)$ і $3,2 \%(\mathrm{P}<0,001)$ порівняно 3 
3-ю та 4-ю групами відповідно. Кури 3-ї групи, яких утримували за помаранчевого світла, не досягали нормативу лише на 0,1 \% та поступалися несучкам 4-ї групи, яких утримували за червоного світла, на 2,8 \% $(\mathrm{P}<0,001)$.

Отримані дані щодо несучості на початкову та середню несучку узгоджуються 3 результатами інших дослідників (Gongruttananun, 2011; Hassan et al., 2013; Huber-Eicher et al., 2013; Svobodova et al., 2015; Zhang et al., 2017), які описують підвищення несучості курей за впливу червоного світла. Цей ефект обумовлений чутливістю саме позасітківкових фоторецепторів гіпоталамусу до довгохвильового випромінювання, а не сприйняттям кольору світла через сітківку ока (Renema et al., 2001; Mobarkey et al., 2010).

Маса яєць несучок кросу "Нy-Line W-36" у 52тижневому віці повинна становити 62,9 г, а споживання корму - 97-103 г/добу на 1 голову (Hy-Line W36 Final Hybrid Content Guide, 2019). Як видно 3 дослідних даних (табл. 2), маса яєць несучок всіх груп відповідала нормі, а витрати корму були вищими за нормативний рівень. Зокрема, нижча маса яєць виявлена у курей 2-ї групи, яких утримували за жовтого світла, на 0,3\% (P<0,05) та 0,5\% (P<0,001) порівняно 3 1-ю та 4-ю групами відповідно, а у курей 3-ї групи, яких утримували за помаранчевого світла, - на $0,3 \%$ ( $<$ 0,05) порівняно з 4-ю групою. Однак різниця за масою яєць між групами була незначною і не відображала зменшення довжини хвилі світла.

Що стосується витрат корму, то найнижче його споживання спостерігалось у курей 1-ї групи, яких утримували за блакитного світла, однак з перевищенням нормативу на 10,8 г, або 10,5 \%. Водночас у курей 1-ї групи споживання корму було нижчим на 1,0 \% (P < 0,001) порівняно з 2-ю групою та на 2,9\% $(\mathrm{P}<0,001)$ і 3,1 \% (P < 0,001) порівняно з 3-ю та 4-ю групами відповідно. Кури 2-ї групи, яких утримували за жовтого світла, споживали менше корму на 2,0\% (P $<0,001)$ та 2,1 \% (P < 0,001) порівняно з 3-ю та 4-ю групами відповідно, за цього перевищували нормативні показники на 11,6 \%. Кури 3-ї групи, яких утримували за помаранчевого світла, характеризувались нижчим споживанням корму на 0,2 \% (P < 0,05) порівняно 3 4-ю групою та перевищували нормативні показники на 13,8 \%. Своєю чергою кури 4-ї групи, яких утримували за червоного світла, характеризувалися найвищим споживанням корму 3 перевищенням нормативу на 14,0 \%.

\section{Висновки}

1. Зменшення довжини хвилі світла під час утримання курей в клітках багатоярусних батарей чинить вплив на їхню життєздатність та репродуктивну функцію. Зменшення пікової довжини хвилі від 653 до 632 нм, яке проявлялось зміною кольору світла з червоного до помаранчевого, супроводжувалось зниженням збереженості поголів'я на 0,3 \% (0,3\% < норми), маси тіла - на 0,8 \% в межах норми, несучості на початкову несучку - на 3,1 \% (4,2\% < норми), несучості на середню несучку - на 2,8\% $(0,1 \%<$ норми) та витрат корму - на $0,2 \%$ (13,8 \% > норми).
2. Зменшення пікової довжини хвилі до 603 нм, тобто зміна кольору світла 3 червоного та помаранчевого на жовте, супроводжувалось зниженням збереженості поголів'я на 6,4-6,7 \% (9,0 \% < норми), маси тіла - на 0,5-1,3 \% в межах фізіологічної норми, несучості на початкову несучку - на 7,1-10,0 \% (11,0\% < норми), несучості на середню несучку - на 0,4-3,2 \% $(0,7 \%<$ норми) та витрат корму - на 2,0-2,1\% (13,8\%> норми).

3. Зменшення пікової довжини хвилі до 458 нм, тобто зміна кольору світла 3 червоного, помаранчевого та жовтого на блакитне, супроводжувалось зниженням збереженості поголів'я на 3,2-9,9 \% (12,2 \% < норми), маси тіла - на 5,2-6,5 \% (5,1 \% < норми), несучості на початкову несучку - на 6,4-15,8 \% (16,8 \% < норми), несучості на середню несучку - на $2,9-6,0 \%(3,6 \%<$ норми) та витрат корму - на 1,0 $3,1 \%$ (10,5\%> норми).

Відомості про конфлікт інтересів. Автори стверджують про відсутність конфлікту інтересів щодо їхнього вкладу та результатів досліджень.

\section{References}

Borille, R., Garcia, R. G., Naas, I. A., Caldara, R. F., \& Santana, M. R. (2015). Monochromatic lightemitting diode (LED) source in layers hens during the second production cycle. Revista Brasileira de Engenharia Agrícola e Ambiental, 19(9), 877-881. doi: 10.1590/1807-1929/agriambi.v19n9p877-881.

Borille, R., Garcia, R. G., Royer, A. F. B., Santana, M. R., Colet, S., Naas, I. A., Caldara, F. R., Almeida, Paz I. C. L., Rosa, E. S., \& Castilho, V. A. R. (2013). The use of light-emitting diodes (LED) in commercial layer production. Brazilian Journal of Poultry Science, 15(2), 135-140. doi:10.1590/S1516-635X2013000200009.

Gongruttananun, N. (2011). Influence of red light on reproductive performance, eggshell ultrastructure, and eye morphology in Thainative hens. Poultry science, 90, 2855-2863. doi: 10.3382/ps.2011-01652.

Er, D., Wang, Z., Cao, J., Chen, Y. (2007). Effect of monochromatic light on the egg quality of laying hens. Journal of Applied Poultry Research, 16(4), 605-612. doi: 10.3382/japr.2006-00096.

Hassan, M. R., Sultana, S., Choe, H. S., \& Ryu, K. S. (2013). Effect of monochromatic and combined light colour on performance, blood parameters, ovarian morphology and reproductive hormones in laying hens. Italian Journal of Animal Science, 12(3), 359364. doi: 10.4081/ijas.2013.e56.

Hy-Line W-36 Final Hybrid Content Guide (2019). URL: https:/www.hyline.com/userdocs/pages/36_COM_RU S.pdf.

Huber-Eicher, B., Suter, A., \& Spring-Stähli, P. (2013). Effects of colored light-emitting diode illumination on behavior and performance of laying hens. Poultry science, 92, 869-873. doi: 10.3382/ps.2012-02679.

Kim, M. J., Choi, H. C., \& Suh, O. S. (2010). A study of different sources and wavelengths of light on laying egg characteristics in laying hens. Korean Journal of Poultry Science, 37, 383-388. doi: 10.5536/kjps.2010.37.4.383. 
Lewis, P. D., Caston, L., \& Leeson, S. (2007). Green light during rearing does not significantly affect the performance of egg-type pullets in the laying phase. Poultry Science, 86, 739-743. doi: 10.1093/ps/86.4.739.

Li, G., Li, B., Zhao, Y., Shi, Z., Liu, Y., \& Zheng, W. (2019). Layer pullet preferences for light colors of light-emitting diodes. Animal, 13(6), 1245-1251. doi: $10.1017 /$ S1751731118002537.

Li, D. Y., Wu, N., Tu, J. B., Hu, Y. D., Yang, M. Y., Yin, H. D., Chen, B. L., Xu, H. L., Yao, Y. F., \& Zhu, Q. (2015). Expression patterns of melatonin receptors in chicken ovarian follicles affected by monochromatic light. Genetics and Molecular Research, 14(3), 10072-10080. doi: 10.4238/2015.August.21.14.

Li, X., Zheng, Z., Pan, J., Jiang, D., Tian, Y., Fang, L., \& Huang, Y. (2020). Impacts of colored light-emitting diode illumination on the growth performance and fecal microbiota in goose. Poultry science, 99(4), 1805-1812. doi: 10.1016/j.psj.2019.12.034.

Manser, C. E. (1996). Effects of lighting on the welfare of domesticpoultry: a review. Animal Welfare, 5(4), 341360. URL: https://www.ingentaconnect.com/contentone/ ufaw/aw/1996/00000005/00000004/art00002.

Mobarkey, N., Avital, N., Heiblum, R., \& Rozenboim, I. (2010). The role of retinal and extra-retinal photostimulation in reproductive activity in broiler breeder hens. Domestic Animal Endocrinology, 38, 235-243. doi: 10.1016/j.domaniend.2009.11.002.

Min, J. K., Hossan, M. S., Nazma, A., Jae, C. N., Han, T. B., Hwan, K. K., Dong, W. K., Hyun, S. C., Hee, C. C., Ok, S. S. (2012). Effect of monochromatic light on sexual maturity, production performance and egg quality of laying hens. Avian Biology Research, 5, 69-74. doi: 10.3184/175815512X13350270679453.

Mudhar, A. S., \& Tabeekh, A. (2016). The effect of color light and stocking density on some enzymes and hormones of broilers and layers. Mirror of Research in Veterinary Sciences and Animals, 5(1), 25-37. doi: 10.5923/j.zoology.20160602.02.

Patel, S. J., Patel, A. S., Patel, M. D., \& Patel, J. H. (2016). Significance of light in poultry production: a review. Advancements in Life Sciences, 5, 1154-1160. URL: http://advancesinlifesciencesjournal.com/upload/074016_(S_J_Patel)_(REVIEW_P.pdf.

Prayitno, D. S., Phillips, C. J. C., \& Omed, H. (1997). The effects of color of lighting on the behavior and production of meat chickens. Poultry science, 76, 452-457. doi: 10.1093/ps/76.3.452.
Prescott, N. B., \& Wathes, C. M. (1999). Spectral sensitivity of domestic fowl (Gallus g. domesticus). British Poultry Science, 40, 332-339. doi: 10.1080/00071669987412.

Renema, R. A., Robinson, F. E., Feddes, J. J. R., Fasenko, G. M., \& Zuidhof, M. J. (2001). Effects of light intensity from photostimulation in four strains of commercial egg layers: 2. Egg production parameters. Poultry science, 80, 1121-1131. doi: 10.1093/ps/80.8.1121.

Rozenboim, I., Biran, I., Uni, Z., Robinzon, B., \& Halevy, O. (1999). The effect of monochromatic light on broiler growth and development. Poultry science, 78, 135-138. doi: 10.1093/ps/78.1.135.

Rozenboim, I., Zilberman, E., \& Gvaryahu, G. (1999). New monochromatic light source for laying hens. Poultry Science, 77, 1695-1698. doi: 10.1093/ps/77.11.1695.

Shi, H., Li, B., Tong, Q., Zheng, W., Zeng, D., \& Feng, G. (2019). Effects of LED Light Color and Intensity on Feather Pecking and Fear Responses of Layer Breeders in Natural Mating Colony Cages. Animals: an open access journal from MDPI, 9(10), 814. doi: 10.3390/ani9100814.

Sultana, S., Hassan, M. R., Choe, H. S., Kang, M. I., \& Ryu, K. S. (2013). Effect of various LED light color on the behavior and stress response of laying hens. Indian Journal of Animal Sciences, 83, 829-833.

Svobodova, J., Tumova, E., Popelarova, E., \& Chodova, D. (2015). Effect of light colour on egg production and egg contamination. Czech Journal of Animal Science, 60, 550-556. doi: 10.17221/8597-CJAS.

Yang, Y., Yu, Y., Pan, J., Ying, Y., \& Zhou, H. (2016). A new method to manipulate broiler chicken growth and metabolism: Response to mixed LED light system. Scientific Reports, 6, 25972. doi: 10.1038/srep25972.

Yenilmez, L. F., Saber, S. N., Serbester, U., \& Celik, L. (2021). Effects of monochromatic light on performance, egg quality, yolk cholesterol and blood biochemical profile of laying hens. The Journal of Animal \& Plant Sciences, 31(1), 46-52. doi: 10.36899/JAPS.2021.1.0191.

Zhang, X., Hongqing, X. U., Monan, L. I., Hongmei, X. U., Muqing, L. I. U. (2017). Effects of different monochromatic light of LED on the growth performance of Jinmao broilers and egg laying performance of Jinmao breeders. Journal of Science and Technology in Lighting, 41, 143-147. doi: 10.2150/JSTL.IEIJ160000592. 